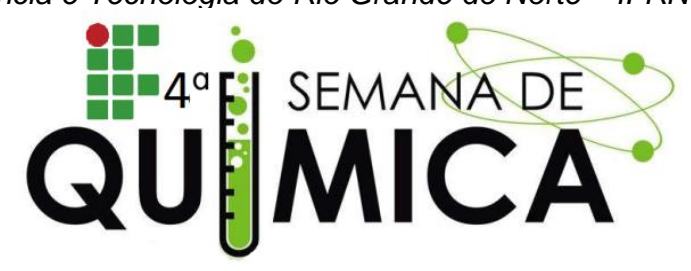

\title{
SÍNTESE DE CARVÃO ATIVADO A PARTIR DO ENDOCARPO DO COCO-DA-BAÍA (Cocos nucifera Linn) APLICADO AO PROCESSO DE ADSORÇÃO DE POLUENTES DA ÁGUA
}

AZEVEDO, J. F. (IFRN); SILVA, T. P. (IFRN); SILVA, D. V. (IFRN); SILVA, J. B. (IFRN); OLIVEIRA, R. A.(IFRN); PENHA, F. G. (IFRN)

Palavras Chave: Endocarpo do coco, carvão ativado, adsorção.

\section{INTRODUÇÃO}

O carvão ativado é considerado como um tipo de carbono puro de enorme porosidade que pode ser produzido a partir de vários precursores ligninocelulósicos ${ }^{1,2}$. O presente trabalho tem como objetivo preparar carvão ativado, por ativação química, a partir do endocarpo de coco para remoção de poluentes no tratamento de água.

\section{METODOLOGIA}

Em laboratório o precursor foi impregnado usando dois ativantes, $\mathrm{KOH}$ e $\mathrm{ZnCl}_{2}$ numa proporção em massa 1,00:0,50 precursor/ativante. Após, realizou-se a pirólise, que ocorreu num forno mufla a $500^{\circ} \mathrm{C}$ durante 30 minutos. $\mathrm{O}$ carvão obtido foi lavado com $\mathrm{HCl}$ $6 \mathrm{M}$ e água destilada e seco em estufa. Por fim, fez-se o teste de adsorção do corante azul de metileno onde a quantidade de corante foi determinada por UV-Vis. Todos os procedimentos foram realizados nos laboratórios do IFRN-Nova Cruz.

\section{RESULTADOS E DISCUSSÃO}

A Figura 1 mostra um teste qualitativo na remoção do corante com concentração de 250 ppm e temperatura ambiente e tempo de contato de 1 hora com os carvões preparados e comparados a um carvão comercial. As mesmas condições foram realizadas para o teste quantitativo, Figura 2. Nota-se que o carvão mais eficiente foi o obtido com o $\mathrm{ZnCl}_{2}$, que apresentou características de remoção semelhantes ao carvão comercial.

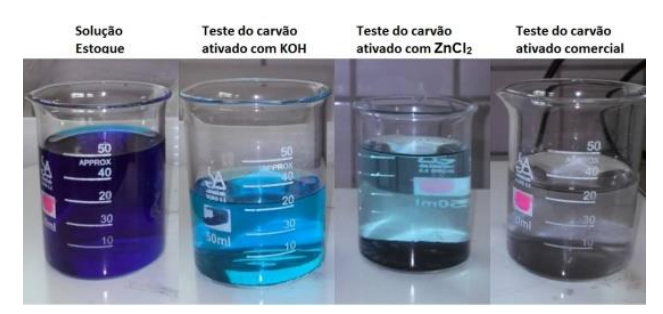

Figura 1 - Comparação da eficiência da adsorção de azul de metileno em diferentes carvões ativados.

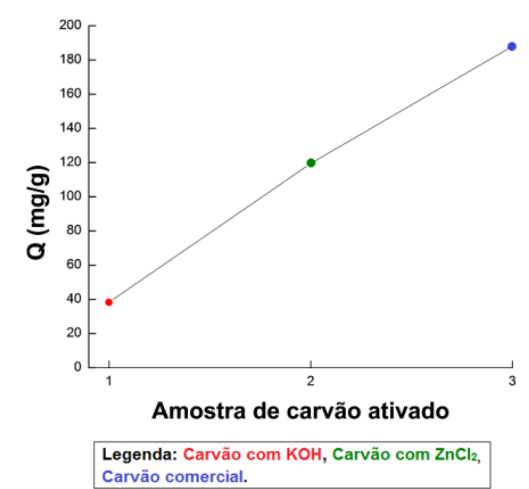

Figura 2 - Quantidades adsorvidas de corante azul de metileno com os carvões ativados.

\section{CONCLUSÃO}

Foi possível a obtenção de carvão ativado a partir do endocarpo de coco, usando cloreto de zinco como ativador, com características de remoção de cor semelhantes a um carvão comercial.

\section{REFERÊNCIAS}

${ }^{1}$ Ozdemir, I.; Sahin, M.; Orhan, R.; Erdem, M.; Fuel Process. Tech. 125, 200-206, 2014.

2Pezoti Jr., O.; et al; Journal of Ind. Eng. Chem. 20, 4401-4407, 2014. 